\title{
Accounting for the Digitalization Factor in Assessing Territorial Competitiveness
}

\author{
E.O. Dmitrieva ${ }^{1, *}$ and M.S. Guseva ${ }^{1}$ \\ *Corresponding author: dmitr-el@mail.ru \\ ${ }^{1}$ Samara State University of Economics, Samara, Russia
}

\begin{abstract}
The study considers approaches in assessing territorial competitiveness at the present stage. The authors propose to take into account the digitalization factor as one of the key in assessing territorial competitiveness, which is associated with current trends in socio-economic development. The study presents the structure of competitiveness and made proposals for taking into account the digitalization factor in assessing territorial competitiveness. The results of the study will contribute to the development of an appropriate methodology.
\end{abstract}

Keywords: assessment, competitiveness, digital economy, digitalization, methodology, territory.

\section{Introduction}

Territorial competitiveness refers to fairly new objects of analysis. As a multi-valued category (territorial competitiveness within one state; territorial competitiveness of a state with territories of other states; competition among macro-regions, etc.), territorial competitiveness is the subject of study of various economic branches.

In general, competitiveness is the ability of a subject to realize its mission (purpose, functions, tasks) with the necessary quality and value in a competitive market. Territorial competitiveness is defined as the ability to maintain a relatively high level of income and employment, while remaining open to international competition. In the research contour, competitiveness refers to estimates and implies the existence of the object (what is being assessed), the subject (who assesses), the criteria and objectives of assessment. The subjects can be government and municipal authorities, investors, development institutions, buyers, etc. The objects of assessment are the country, territory, enterprise, and product. The criteria for assessing competitiveness can be the pace of development based on certain indicators. Therefore, competitiveness as a multifaceted concept can be characterized from different positions depending on the tasks to be solved [1]. This study focuses on the need to update approaches to assessment of competitiveness, taking into account digital transformations of socio-economic development.

\section{Problem Statement}

In recent decades, in domestic science, competitiveness of spatial socio-economic systems of different levels (countries, regions, cities) has been actively discussed. V. N. Ukrainskii notes the gaps in the conceptualization of competitiveness and its application to spatial socio-economic systems, and also points to a number of unresolved problems in the methodological, theoretical and empirical sections [2].

The most cited works in the Russian Federation are the following:

- Methods of integral assessment of region's strategic and current competitiveness [3];

- Assessment of competitiveness based on the results of region's activities [4];

- Study of territorial competitiveness [5].

The developed and approved methods for assessing territorial competitiveness have their pros and cons. Most of the approaches are based on the calculation of integral values of competitiveness and comparative rating estimates. In a number of works devoted to the development of territories, competitiveness is identified with a high level of digitalization [6]. However, it is difficult to agree with this, since digitalization can have a positive and also a negative impact on other competitive factors.

The problems of assessing competitiveness are determined by multifaceted properties and functions of the territory as a subject of development, the choice and justification of indicators, and information support for the assessment process. Territorial competitiveness requires adequate theoretical and methodological support if this issue is one of the state tasks. 


\section{Research Questions}

Economic scholars focus on different aspects of territorial competitiveness. Various methods for assessing territorial competitiveness are given. It is determined that the same tools and methods for analyzing countries' and regions' competitiveness can be adapted to the analysis of competitiveness at the local level. The combination of econometric and qualitative measurement methods gives a comprehensive picture of urban competitiveness and its future prospects [7]. Some authors assess territorial competitiveness by one or several indicators. Others have developed theoretical models of urban competitiveness, combining quantitative and qualitative indicators in a complex, focused on the development of integrated assessment of economic and non-economic aspects of urban competitiveness [8, 9]. In the works of foreign researchers, competitiveness is assessed by a multi-level system of index indicators of territory development. The assessment of competitiveness of Chinese cities is based on a multi-level hierarchical model built on the index method and spatial analysis [10,11]. In the empirical study, competitiveness is analyzed on the basis of innovative indicators from three positions: the formation of clusters, human capital and the creative economy [12]. In assessing competitiveness, its sources are identified, which makes it possible to choose the ways of the most efficient allocation of resources in the development and implementation of government programs [13].

In this regard, the following research questions are formulated:

1. Determine the impact of digitalization on territorial competitiveness;

2. Identify areas of digital development of the territories of the Russian Federation and justify the need to take them into account in assessing competitiveness.

\section{Purpose of the Study}

The purpose of the study is to include the digitalization factor in assessment of the competitive methodology. It is established that the effect of digitalization on other factors of territorial competitiveness is little studied. The hypothesis of the study is that digitalization can have not only a positive, but also a negative impact on other factors of competitiveness. The confirmation of this hypothesis may have an impact on the development of the theoretical and methodological basis for assessing territorial competitiveness.

\section{Research Methods}

The study uses methods of system and structural analysis. A modeling method is used for the development of theoretical and methodological bases for assessing territorial competitiveness, taking into account programs and projects operating in the Russian Federation in the field of digital development.

\section{Findings}

Currently, the Russian Federation is implementing the priority program "Digital Economy of the Russian Federation", aimed at increasing the country's competitiveness, quality of life of citizens, ensuring economic growth and national sovereignty.

The digital economy is represented by three levels, which in their close interaction affect the lives of citizens and society as a whole: markets and sectors of the economy (areas of activity), where specific subjects (suppliers and consumers of goods, works and services) interact; platforms and technologies where competencies are formed for the development of markets and sectors of the economy (spheres of activity); the environment that creates conditions for the development of platforms and technologies and the effective interaction of market entities and sectors of the economy (spheres of activity) and covers the regulatory framework, information infrastructure, personnel and information security [14].

To assess the readiness of countries for the digital economy, the latest version of the international index of network readiness is applied. The index assesses the factors affecting the development of the digital economy, and shows how effectively countries use digital technologies to improve their competitiveness and well-being.

The presented approach to the development of a methodological basis for assessing territorial competitiveness considers the definition that digital data is a key factor of production in all areas of socio-economic activity, and the use of digital technologies contributes to competitiveness and well-being. Digital technologies are very important in creating a competitive advantage of the territory.

Under current conditions, the introduction of platform solutions and the increased use of information and communication technologies (ICT) in all spheres of life activities are to become the most important factors for increasing territorial competitiveness. The digital development of territories is becoming an indispensable tool that can stimulate the susceptibility of state and business structures to innovations, as well as increase their innovation activity [15]. These trends determine the objective need to take into account the digitalization factor in existing methods for assessing territorial competitiveness. 
Taking into account the integral nature of territorial competitiveness and its definition as the ability to withstand competition, we can distinguish three integrated types of markets in which territorial competitiveness is presented: the market for the production of goods, labor and capital. In accordance with this, the following structure of territorial competitiveness is proposed, taking into account modern digital transformations of the economy (Fig. 1).

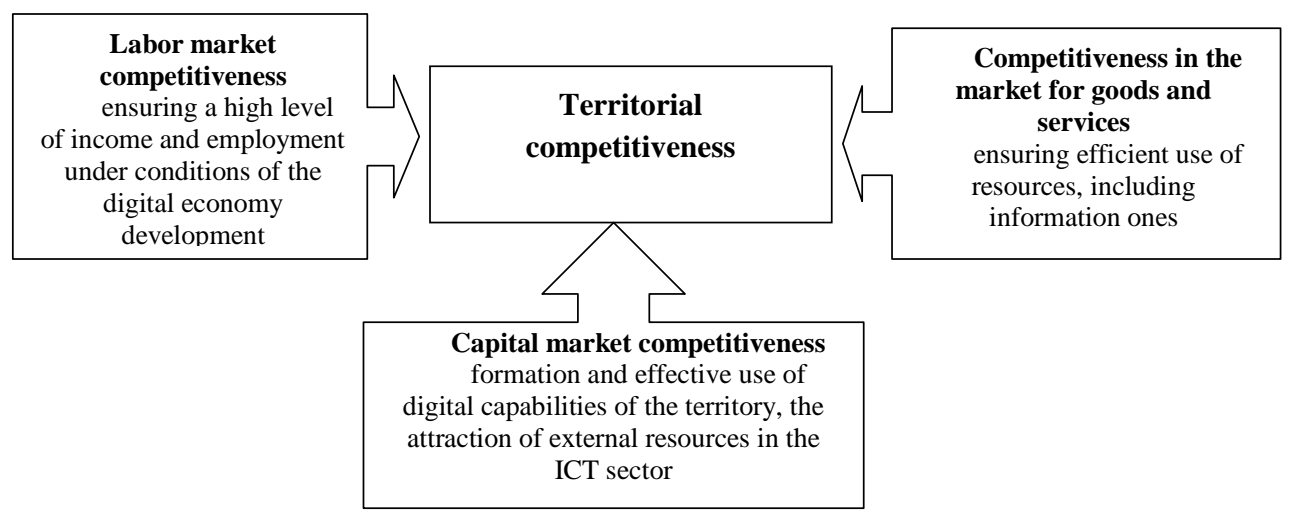

Figure 1. The structure of territorial competitiveness, taking into account the digitalization factor (Source: compiled by the authors)

To ensure territorial competitiveness, the labor market must rely on the requirements of the digital economy, the creation of conditions for the training of new personnel and the development of digital competencies. The recognition of digital competencies as the most demanded at the present stage is to intensify the development of digital skills, to overcome the digital inequality among certain groups of the population.

Under the influence of digitalization, the market for goods and services is changing dramatically. Traditional industries are being supplanted by new sectors of the economy, generating new needs for consumers. In this regard, the formation of flexible institutions and adaptive infrastructure to support business structures, information security of business activities will be required. Under current conditions, competitiveness should be ensured by facilitating the entry of capital into investment projects for the development of the territory and the creation of preferences for domestic producers of information technologies.

In assessing territorial competitiveness, the digital inequality should be taken into account - the inability of a certain group of people to access modern ICT, ICT in everyday life, and differences in ICT equipment. The digital inequality increases the already noticeable competitive advantage of the rich to the poor, excluding the participation of the latter in the modern digital economy. As a complex socio-economic phenomenon, the digital inequality has many forms on a global scale, as a separate state, region or municipality. The digital inequality has both internal and external meaning. In the first case, it is the stagnation of the level of informatization outside large cities while there are no measures to overcome the information gap of individual territories.

\section{Conclusion}

The digitization of socio-economic development processes directly affects the structure of territorial competitiveness, and, accordingly, should change the existing approaches to its assessment. From a methodological point of view, it is necessary to take into account the indicators of the information society development, to introduce digital services in the social infrastructure, indicators of the digital economy development, as well as the level of interaction of citizens, business and government based on digital technologies.

\section{References}

1. L.S. Shekhovtseva, The concept of competitiveness of the region. Problems of the Modern Economy, 3(23), 276-280 (2007).

2. V.N. Ukrainskii, Regional competitiveness: methodological reflections. Voprosy Ekonomiki, 6, 117-132 (2018).

3. L.S. Shekhovtseva, E.V. Tyapushova, Theoretical and methodological foundations of the integral assessment of the strategic and current competitiveness of the region. Regional Economy: Theory and Practice, 20(213), 7-18 (2011).

4. E.A. Kolomak, Analysis of factors of regional competitiveness. Region: Economy and Sociology, 3, 87-115 (2009).

5. S.G. Vazhenin, I.S. Vazhenina, Outlines of territorial competition. Region: Economy and Sociology, 2, 271-288 (2008).

6. Kh.S. Kazancheva, A.L. Kilchukova, Prospects for the strategic management of the region's economy in the conditions of knowledge asymmetry in the realities of the digital economy. News of the Kabardino-Balkarian Scientific Center of the Russian Academy of Sciences, 6(80), 143-151 (2017). 
7. J. Bruneckiene, R.Cincikaite, A. Kilijoniene, The specifics of measurement the urban competitiveness at the national and international level. [Miestų konkurencingumo vertinimo nacionaliniu ir tarptautiniu mastu ypatumai]. Engineering Economics, 23(3), 256-270. DOI:10.5755/j01.ee.23.3.1272 (2012).

8. R. Hu, Sustainability and competitiveness in Australian cities. Sustainability (Switzerland), 7(2), $1840-1860$. DOI:10.3390/su7021840 (2015).

9. R. Hu, E.J. Blakely, Y. Zhou, Benchmarking the competitiveness of Australian global cities: Sydney and Melbourne in the global context. Urban Policy and Research, 31(4), 435-452. DOI:10.1080/08111146.2013.832667 (2013).

10. Q. Du, Y. Wang, F. Ren, Z. Zhao, H. Liu, C. Wu, L. Li, Y. Shen, Measuring and analysis of urban competitiveness of Chinese provincial capitals in 2010 under the constraints of major function-oriented zoning utilizing spatial analysis. Sustainability (Switzerland), 6(6), 3374-3399. DOI: 10.3390/su6063374 (2014).

11. L. Wang, J. Shen, Comparative analysis of urban competitiveness in the Yangtze river delta and Pearl river delta regions of China, 2000-2010. Applied Spatial Analysis and Policy, 10(3), 401-419. DOI:10.1007/s12061-016-92106 (2017)

12. S. Kwon, J. Kim, D.-S. Oh, Measurement of urban competitiveness based on innovation indicators in six metropolitan cities in Korea. World Technopolis Review, 1(3), 177-185. DOI: 10.7165 / wtr2012.1.3.177 (2012).

13. M. Akpinar, Ö. Can, M. Mermercioglu, Assessing the sources of competitiveness of the US states. Competitiveness Review, 27(2), 161-178. DOI: 10.1108/CR-02-2016-0014 (2017).

14. Rasporyazheniye Pravitel'stva Rossiyskoy Federatsii "Ob utverzhdenii programmy "Tsifrovaya ekonomika Rossiyskoy Federatsii»" ot 28.08.2017 N 1632 -r. $\quad$ Retrieved from: http://static.government.ru/media/files/9gFM4FHj4PsB79I5v7yLVuPgu4bvR7M0.pdf. $\quad$ Accessed: 08.01 .2019 (2017). [in Rus.].

15. Expert Analytical Report. Priority directions for the introduction of smart city technologies in Russian cities. Retrieved from: https:/www.csr.ru/wp-content/uploads/2018/06/Report-Smart-Cities-WEB.pdf. Accessed: 1/8/2019 (2018). [in Rus.]. 